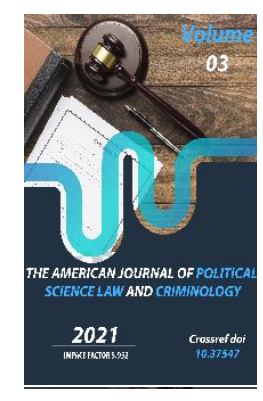

\title{
Issues Of Using And Legal Regulation Of Digital Technologies In The Provision Of Medical Services
}

\author{
Jaloliddin Tuychiyevich Askarov
}

Lecturer And Independent Researcher At Tashkent State University Of Law, Uzbekistan

Copyright: Original

content from this work may be used under the terms of the creative commons attributes 4.0 licence.

\section{ABSTRACT}

This article analyzes the issues of digitalization and legal regulation of medical services. The concept of digital medicine and its various definitions have been studied and attitudes have been expressed in the provision of modern medical services. Conclusions and recommendations on the regulation of digital medicine are given.

\section{KEYWORDS}

Law, digitalization of medicine, legal regulation, telemedicine, medical services, digital technology.

\section{INTRODUCTION}

The century of information and digital technology are changing lifestyle, giving various advantages to humanity. As a result this, new concepts, rules and legal constructions are emerging in many areas. The modern world today can not be imagined without the Internet. The Internet has undergone penetration into every sphere, 
family and society. In particular, the global pandemic, which has been going on since the beginning of 2020 year, has encouraged many to work, read, serve online.

Including in the field of medicine, this process has transformed faster than ever. This is particularly evident in the successes and failures of treatment modalities and in the remote exchange of views on Covid-19 [1]. Concepts such as digitalization, the use of digital technologies, the use of artificial intelligence and nanotechnology are taking place in our vocabulary in every field. Of course, the speed of innovation and technological processes is felt more in the areas that directly serve mankind or make their life easier.

This can be seen as an example in the field of medical services.

The speed and quality of providing medical services to the population is an important factor in the digitization of medicine.

True, at first glance, not only in medicine, but also in sports, jurisprudence, education and other fields, there is of course an it, artificial intelligence or Internet network that we imagine when it comes to the issue of digitalization and legal framework for its application.

However, the high level of the human factor in the provision of medical services, the fact that life is given once for a person and requires a serious attitude towards him, does not exclude the determination of a certain limit, object, legal solutions and a territory beyond the limits of law to liability in the digitalization of medicine.
Therefore, in the legal regulation of digitization and surrounding processes, it is necessary to take into account both the digitalization and the specifics of other areas.

According to T.Y. Khabrieva and N.N. Chernogor "Modern digital technologies serve not only the formation of a new digital reality, but also the formation of new methods of production" [2].

In the digital economy itself, there are signs that are important for the functioning of each sphere. The most important issue is economic relations related to the development of IT and artificial intelligence. Digital technologies are entering various segments of the economy, including banking, retail, energy, transportation, education, media, health, information and communication.

According to Russian scientists, "Digital medicine is a system of scientific knowledge and practical activities in the field of diagnosis, treatment and prevention of disease, information and communication technologybased treatment and care of the physically and mentally ill on the basis of a digital health platform that maintains and strengthens human health and ability to work, prolongs life, as well as collects, maintains and develops a system of scientific knowledge in medicine [3].

At first glance, this definition seems to cover all aspects of medical care, but there is onesidedness in the definition given by scientists. One-sidedness is more focused on disease prevention and treatment alone.

Entrepreneurs claim that "digital medicine is a product that undergoes rigorous clinical testing and / or ultimately has a direct impact on the detection, prevention, control, or 
treatment of disease" [4]. In this regard, business entities equate the digitalization of medicine to the product, focusing on the prevention and treatment of diseases. By Joseph C Kvedar, Alexander Fogel, Eric Elenko, and Daphne Zohar, digital medicine is considered a new type of most dynamic interdisciplinary practice in terms of theory, knowledge, technology, methodology and innovation [5]. Digital medicine has been making use of it products, as it has been performing the latest paradigms and methods of imaging and operating with the help of robots in recent times.

In the above definition, the main features of the natural and exact sciences are adapted to modern development, in which I think it is more accurate to say that it is a practical approach to the digitalization of medicine, rather than a legal boundary or regulation.

When it comes to statistics, digital innovation has become a leading platform for global economic growth.

It is estimated that Internet technology will account for $22 \%$ of GDP growth in China by 2025, while digital technology in the US is expected to grow by $\$ 1.6-2.2$ trillion by 2025 , and the economic benefits of digitalization the Russian economy by 2025.4.1-8.9 trillion by the year. [6].

Such high rates of economic growth and the pace of technological processes are also beneficial for our country. This was particularly evident during the pandemic, when medical services were provided online and offline. Paid and free consultations in the form of telemedicine are examples of this. The above definitions of digital medicine by various industry representatives are general definitions, not to limit or regulate industry activities, and are important in legal regulation. However, we do not think it is appropriate to give a legal definition to the concept of digital medicine and put a strict limit on it, because as technological processes and the human factor diminish, any definition can adapt to it. In addition, a number of medical and technical terms such as telemedicine, HealthNet, HealthTech, eTibbiyot, eKarta are entering our lives today.

In addition, it should be noted that the importance of medical tourism today is growing [7, pp. 79-80]. In particular, as medical services become more sophisticated, today's technology regulations provide for the use of digital technologies in this area and the establishment of a legal order. This requires the development of popular maps of areas specializing in tourism and ensuring the quality of the Internet in long areas [8, p. 23].

The emergence of new legal relationships related to digital medicine also poses a number of challenges to the legal field. Admittedly, the technological capabilities of smartphones and gadgets have evolved from the heartbeat to what diseases are present in our body. Now patients can easily find out their medical problems without going to the hospital. Therefore, first of all, it is necessary to determine in the medical protocols what types of medical services are digitized, programmed and telemedicine.

Second, patient rights need to be guaranteed even when using any form of medical services. This process, in particular, needs to be defined by a certain boundary between consulting a specialist remotely and being present in front 
of a specialist, as the human factor can endanger human life by failing to disclose details requested by a doctor or concealing them as a personal secret.

Third, it is necessary to provide a system for the formation and electronization of patient databases. Adequate facilities are needed, especially for public health facilities. Fourth, we consider it expedient to specify in the forthcoming Civil Code and Healthcare Code the issue of electronic document circulation, the use of means of identification in the conclusion of contracts, the consequences of non-performance of obligations.

\section{CONCLUSION}

In conclusion, the use of advanced technologies in the provision of medical services has become a mean of bringing the weight of everyone, not only today, but light, distances closer. In this process, it is necessary to apply the mechanisms of legal regulation, on the basis of which the relationship moving from the usual to the electronic form should be reconsidered. In creating legal framework, it is advisable to take into account the scientific and theoretical conclusions, the application of general and specific principles of law.

\section{REFERENCES}

1. https://kun.uz/news/2021/02/13/toshke nt-tibbiyot-akademiyasidakoronavirusga-aloqador-mavzudaxalqaro-konferensiya-bolib-otdi

2. Хабриева Т.Я., Черногор Н.Н. Право в условиях цифровой реальности// Журнал российского права. 2018. № 1. C. 85-102.

3. Карпов О. Э., Субботин С. А., Шишканов А. В., Замятин М. Н.
Цифровое здравоохранение. Необходимость и предпосылки https://cyberleninka.ru/article/n/tsifrov oe-zdravoohranenie-neobhodimost-ipredposylki/viewer

4. Elenko E, Underwood L, Zohar D. Nat Biotechnol. 2015 May;33(5):456-61. doi: 10.1038/nbt.3222.

5. Kvedar, J. C., Fogel, A. L., Elenko, E., \& Zohar, D. (2016). Digital medicine's march on chronic disease. Nature Biotechnology, 34(3), 239-246. doi:10.1038/nbt.3495

6. Цифровая Россия: новая реальность.Digital McKinsey. Москва, 2017.URL: https://www.mckinsey.com/

7. Аскаров, Ж. (2020). ПРАВОВОЕ РЕГУЛИРОВАНИЕ И СРАВНИТЕЛЬНЫЙ АНАЛИЗ ДЕЯТЕЛЬНОСТИ СУБЪЕКТОВ ПРЕДПРИНИМАТЕЛЬСТВА В СФЕРЕ ОКАЗАНИЯ МЕДИЦИНСКИХ УСЛУГ В ЗАРУБЕЖНЫХ СТРАНАХ. Review of law sciences, 4(Спецвыпуск).

8. Аскаров, Ж. Т. (2020). ТИББИЙ ТУРИЗМНИ ХУҚУҚИЙ ТАРТИБГА СОЛИШ МОХИЯТИ ВА ЎЗИГА ХОС ЖИХАТЛАРИ. ЖУРНАЛ ПРАВОВЫХ ИССЛЕДОВАНИЙ, 5(8). 